Contributions:

A Study design/planning

B Data collection/entry

C Data analysis/statistics

D Data interpretation

E Preparation of manuscript

F Literature analysis/search

$G$ Funds collection

\title{
A RARE CASE OF VASCULAR ANOMALY OF THE VERTEBROBASILAR SYSTEM IN A PATIENT WITH MIXED TYPE VERTIGO
}

\author{
Anna Jałocha-Kaczka ${ }^{\mathrm{E}}$, Marzena Bielińska ${ }^{\mathrm{B}}$, Jarosław Miłoński ${ }^{\mathrm{C}}$, \\ Krzysztof Kuśmierczyk ${ }^{\mathrm{F}}$, Laura Polaczkiewicz ${ }^{\mathrm{F}}$, Jurek Olszewski ${ }^{\mathrm{A}}$
}

Department of Otolaryngology, Laryngological Oncology, Audiology and Phoniatrics, Medical University of Łódź, Poland

Reprint requests to: Jurek Olszewski, Department of Otolaryngology and Laryngological Oncology, Audiology and Phoniatrics, Medical University of Łódź, Żeromskiego 113, 90-549 Łódź, Poland, e-mail: jurek.olszewski@umed.lodz.pl

\begin{abstract}
Background. The aim of the study is to present a patient who suffered from severe vertigo with rare arterial vascular anomaly of the vertebrobasilar system.

Case Report. A 56-year old female patient was urgently admitted due to dizziness, with a spinning motion toward the right, accompanied by nausea, vomiting, and diplopia which occurred on the morning of the day of admission and gradually intensified. The patient had laboratory tests, VNG, functional imaging of the cervical spine, CT of the head, CTA of the cranial arteries, and neurological and ophthalmological consultations. This demonstrated a vascular anomaly in which the basilar artery was an extension of the right vertebral artery, and the left atrophic vertebral artery extended into the posterior inferior cerebellar artery. Conservative treatment and motor rehabilitation gave very good therapeutic effects.

Conclusion. In the presented case, the basilar artery was found to be an extension of the right vertebral artery, while the left atrophic vertebral artery extended into the posterior inferior cerebellar artery. The vascular anomaly, osteochondrosis of the C4/C5 cervical spine, and hyperlipidemia resulted in mixed-type vertigo with decreased excitability of the labyrinth on the affected (anomalous) side due to insufficient blood supply to the inner ear and lack of vascular compensation. The diagnosed anatomical anomaly of the vertebrobasilar system was not an indication for surgical intervention; instead, conservative treatment was successful.
\end{abstract}

Keywords: vascular anomaly $\bullet$ vertebrobasilar system $\bullet$ dizziness

\section{UN CASO RARO DE ANOMALÍA DEL SISTEMA VERTEBRO-BASILAR EN UNA PACIENTE CON VÉRTIGO DE TIPO MIXTO}

\section{Resumen}

Introducción: El trabajo tiene como fin presentar el caso de una paciente con una anomalía rara del sistema vertebro-basilar que sufre vértigo. Descripción del caso: La paciente de 56 años fue ingresado en el hospital de modo urgente por vértigo del tipo "movimientos espirales a la derecha", acompañado de nauseas, vómito y doble imagen. Estas molestias se manifestaron por la mañana el día del ingreso y se iban intensificando gradualmente. Se realizaron las siguientes pruebas: pruebas de laboratorio, una videonistagmografía (VNG), un examen de rayos X funcional de columna cervical, tomografía computarizada (TC) de la cabeza, angiografía por tomografía computarizada (ATC) de vasos sanguíneos intracraneales, así como consultas de neurología y oftalmología. Gracias a las pruebas realizadas se detectó una anomalía vascular: la arteria basilar continuaba como la arteria vertebral derecha y la arteria vertebral izquierda atrófica pasaba a ser la arteria cerebelosa inferior posterior. El tratamiento conservador aplicado y la rehabilitación motora rindieron muy buen resultado terapéutico.

Conclusiones: En el caso presentado, la arteria basilar continuaba como la arteria vertebral derecha y la arteria vertebral izquierda atrófica pasaba a ser la arteria cerebelosa inferior posterior. La anomalía vascular, las alteraciones de columna cervical en forma de osteocondrosis C4/C5 y la hiperlipidemia causaron la aparición del vértigo de tipo combinado con disminución de la excitabilidad del laberinto del lado de la anomalía, lo cual fue causado por la vascularización alterada de las estructuras del oído interno y falta de compensación vascular. La anomalía del sistema vertebro-basilar diagnosticada no constituía una indicación para intervención quirúrgica, es más, el tratamiento conservador resultó ser eficaz.

Palabras clave: anomalías del sistema vertebro-basilar • vértigo

\section{РЕДКИЙ СЛУЧАЙ АНОМАЛИИ ВЕРТЕБРОБАЗИЛЯРНОЙ АРТЕРИАЛЬНОЙ СИСТЕМЫ У ПАЦИЕНТКИ С ГОЛОВОКРУЖЕНИЯМИ СМЕШАННОГО ХАРАКТЕРА.}

\section{Абстракт}

Введение: Целью работы является описание случая пациентки с редкой аномалией вертебробазилярной артериальной системы, с жалобами на головокружения. 
Описание случая: 56-летняя пациентка была экстренно госпитализирована из-за вращательного головокружения в правую сторону с сопутствующей тошнотой, рвотой и раздвоением в глазах. Симптомы появилось в утренние часы в день госпитализации и постепенно усиливались. Были выполнены обследования: лабораторные обследования, видеонистагмография (vng), функциональная рентгенография шейного отдела позвоночника, компьютерная томография (СТ) головы, компьютерная томографическая ангиография (angio-CT) сосудов головного мозга, получена консультация невролога и окулиста. Выполненные исследования выявили сосудистую аномалию - базилярная артерия была продолжением правой вертебральной (позвоночной) артерии, а атрофированная левая вертебральная (позвоночная) артерия переходила в заднюю нижнюю мозжечковую артерию. Примененное консервативное лечение, а также двигательная реабилитация дали очень хороший терапевтический эффект.

Выводы: В представленном случае базилярная артерия была продолжением правой вертебральной (позвоночной) артерии, а атрофированная левая вертебральная (позвоночная) артерия переходила в заднюю нижнюю мозжечковую артерию. Сосудистая аномалия, изменения в шейном отделе позвоночника в виде остеохондроза C4/C5, а также гиперлипидемия повлияли на головокружения смешанного характера со снижением возбудимости лабиринта со стороны аномалии, что было вызвано нарушением кровообращения структур внутреннего уха и отсутствием сосудистой компенсации. Диагностированная аномалия вертебробазилярной артериальной системы не была показанием для хирургического вмешательства, более того, консервативное лечение оказалось эффективным.

Ключевые слова: аномалии вертебробазилярной артериальной системы • головокружения

\section{RZADKI PRZYPADEK ANOMALII UKŁADU KRĘGOWO-PODSTAWNEGO U PACJENTKI Z ZAWROTAMI GLOWY TYPU MIESZANEGO.}

\section{Streszczenie}

Wstęp: Celem pracy jest przedstawienie przypadku pacjentki z rzadką anomalią układu kręgowo-podstawnego cierpiącej z powodu zawrotów głowy.

Opis przypadku: 56letnia pacjentka została przyjęta $\mathrm{w}$ trybie pilnym $\mathrm{z}$ powodu zawrotów głowy o charakterze ruchu wirowego $\mathrm{w}$ prawo $\mathrm{z}$ towarzyszącymi nudnościa, wymiotami i dwojeniem obrazu. Dolegliwości pojawily się w godzinach porannych w dniu przyjęcia i stopniowo narastały. Pacjentka miała wykonane: badania laboratoryjne, badanie videonystagmograficzne (vng), badanie rentgenowskie (rtg) czynnościowe szyjnego odc. Kregosłupa, tomografię komputerową (CT) głowy, angiografię tomografii komputerowej (angio-CT) naczyń doczaszkowych oraz konsultację neurologiczną i okulistyczną. Przeprowadzone badania ujawniły anomalię naczyniową - tętnica podstawna była przedłużeniem prawej tętnicy kręgowej a zanikowa lewa tętnica kręgowa przechodziła w tetnicę tylną-dolną móżdżku. Zastosowane leczenie zachowawcze oraz rehabilitacja ruchowa dały bardzo dobry efekt terapeutyczny.

Wnioski: $W$ przedstawionym przypadku tętnica podstawna była przedłużeniem prawej tętnicy kręgowej a zanikowa lewa tętnica kregowa przechodziła w tetnicę tylną-dolną móżdżku. Anomalia naczyniowa, zmiany w szyjnym odcinku kręgosłupa pod postacią osteochondrozy C4/C5 oraz hiperlipidemia wpłynęły na wystąpienie zawrotów głowy typu mieszanego z zmniejszeniem pobudliwości błędnika po stronie anomalii co było spowodowane upośledzonym ukrwieniem struktur ucha wewnętrznego oraz brakiem kompensacji naczyniowej. Zdiagnozowana anomalia układu kręgowo-podstawnego nie była wskazaniem do interwencji chirurgicznej, co więcej leczenie zachowawcze okazało się skuteczne.

Słowa kluczowe: anomalie układu kręgowo-podstawnego • zawroty głowy

\section{Introduction}

The complex anatomy of the cranial and intracranial arteries, as well as their collateral circulation, has been the subject of study for many years. Currently, Doppler ultrasound imaging is of particular importance, either continuous wave Doppler or colour-coded pulsed wave Doppler. Excellent images are also available using contrast computed tomography angiography (CTA) and magnetic resonance angiography (MRA) [1-5]. All these imaging methods provide understanding of blood flow in the cranial and intracranial vessels under normal conditions or in pathological situations caused by congenital or acquired abnormalities [5-10].

Anomalies of the vertebral arteries include underdevelopment of one vertebral artery (with compensatory dilation of the contralateral artery); total absence of one of the vertebral arteries; variations in vertebral artery origins from the aorta or from the common carotid artery; double origin of one vertebral artery forming a common vascular trunk; and duplication of the vertebral artery on one side [11-12].

The routes of the vertebral arteries can be divided into four sections:
- V1 - initial segment of the artery to the sixth cervical vertebra,

- V2 - in the transverse process canal,

- V3 - distal segment, at the level of the first and second cervical vertebra,

- V4 - intracranially located [6].

The reduction of blood flow caused by a hemodynamically significant factor triggers numerous compensatory mechanisms. These include local regulation of the cerebral circulation, increase in systemic blood pressure, and, in the case of permanent reduction of blood supply, the formation of collateral circulation [1].

These anatomical anomalies do not produce specific symptoms that could prompt early diagnostic tests aimed at their identification, and they often coexist with other disorders that can cause similar symptoms in the ear-nose-throat (ENT) organs (post-traumatic or degenerative changes in the cervical spine, hypertension, hormonal or metabolic disorders).

The aim of this study is to present a patient suffering from severe vertigo who had a rare arterial vascular anomaly of the vertebrobasilar system. 


\section{Case Report}

The female patient, aged 56, was admitted by ambulance one evening to the University Clinical Hospital Military Memorial Medical Academy in Łódź due to severe dizziness, vomiting, and photophobia.

A computed tomography (CT) scan of the head performed the same day revealed no focal changes in the brain; the ventricular system and extracerebral fluid spaces were of normal size, symmetrical, and not dislocated. The area of the cerebellar-pontine angles was normal. Internal auditory canals were of normal width, with smooth bone contours.

On the same day the patient was urgently referred to the Department of Otolaryngology, Laryngological Oncology, Audiology, and Phoniatrics of the Medical University of Łódź. On admission, she complained of severe dizziness, with a spinning motion to the right, accompanied by nausea and vomiting, which first occurred on the morning of the day of admission and gradually intensified. In addition, she complained of double vision when looking to the right and blurring, decreased visual acuity, and narrowing of the visual field on the same side. The patient was conscious, verbally responsive, and had normal orientation to time, place, and person. The anamnesis included no previous ENT treatment and no infection over the last few days. The patient was treated for hypertension and mixed hyperlipidemia. A physical examination noted that the patient could not move independently and was confined to bed. Second degree spontaneous nystagmus to the right was observed. The patient was not able to perform static or dynamic tests.

Laboratory findings revealed that urea, CRP, and total cholesterol were slightly higher than normal and HDL cholesterol was low, but all other parameters (WBC, RBC, HGB, PLT, glucose, creatinine, potassium, chloride, sodium, Ddimer, GFR, TSH, FT3, FT4, triglycerides ) were normal.

Intravenous treatment was given (Ondansetron, $4 \mathrm{mg}$; Vinpocetinum, 2 x $10 \mathrm{mg}$; Piracetam, 1 x $12 \mathrm{~g}$; and fluids, 5\% glucose and multi-electrolytes) and within three days the severity of the symptoms decreased and vomiting subsided. Further diagnostic tests and consultations were scheduled.

A videonystagmography (VNG) examination revealed unsymmetric caloric tests, right-beating directional preponderance, and significantly reduced left labyrinth excitability during the period of compensation.

Audiometric tests yielded normal pure-tone thresholds.

Neurological consultation: The physical examination demonstrated no meningeal signs. There was horizontal nystagmus when looking to the right and periodic diplopia. Apart from this, no signs of damage were observed. In the upper and lower limbs, muscle strength was normal, with symmetrical deep reflexes, no ataxia, and no superficial sensory disorders or pathological symptoms. Dizziness increased with verticalization. The patient was recommended for tests of double vision. In the case of confirmed diplopia, it would be advisable to perform cerebrovascular CTA.
Ophthalmologic consultation: The patient reported diplopia when looking to the right and up, and photophobia. Pupillary reaction to light was symmetrical and correct. There was nystagmus during abduction of the right eye, slight nystagmus during abduction of the left eye, and limitation to upward eyeball movement. The anterior segment of the eye and the fundus were normal for the patient's age. Concentric narrowing of the field of vision in both eyes was observed. Such a nonspecific clinical presentation might indicate neurotic disorders or ischemic areas in the parietal lobe.

Functional imaging of the cervical spine revealed preserved lordosis and decreased height of the $\mathrm{C} 4 / \mathrm{C} 5$ intervertebral disc (chondrosis). There was normal bone structure of the vertebral bodies in the examined segment. Functional images revealed preserved and correct mobility of the spinal motor segments-facet joints.

Ultrasound of the vertebrobasilar arteries showed no variations in the velocity of blood flow in the vertebral and basilar arteries. Abnormal blood flow velocity in the ultrasound in the vertebral and basilar arteries was observed after the neck torsion test, which might suggest the presence of vascular anomalies.

CTA of the cerebral arteries (Fig. 1) demonstrated a developmental anomaly: the basilar artery was an extension of the right vertebral artery, and the atrophic left vertebral artery extended into the posterior inferior cerebellar artery.

After 10 days of treatment, the patient was discharged in good condition, with the following recommendations: pharmacotherapy involving Piracetam $1.2 \mathrm{~g}$ ( $2 \times 1 \mathrm{tab})$ and Vinpocetinum $5 \mathrm{mg}(3 \times 1 \mathrm{tab})$; rehabilitation of the cervical spine at the Outpatient Medical Rehabilitation Clinic; avoidance of sudden head movements, particularly twisting from side to side; avoidance of driving and working at heights until the next examination; VNG examination in one month; further treatment at the Internal Medicine Clinic.

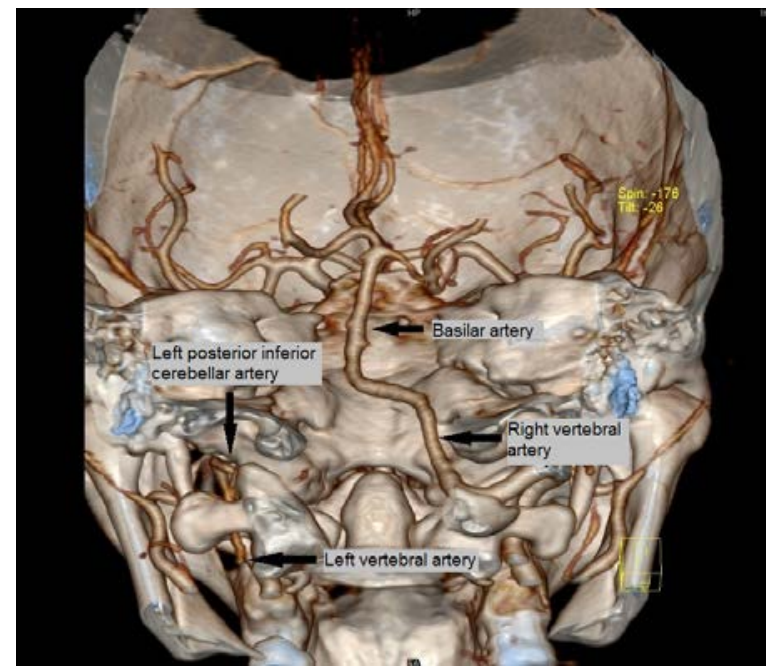

Figure 1. CTA of the vascular anomaly in the vertebrobasilar system of the patient 


\section{Discussion}

Anatomical anomalies often do not produce specific symptoms that might suggest early diagnostic tests to identify them, and they sometimes coexist with other disorders that can cause similar symptoms in the ENT organs (such as post-traumatic or degenerative changes in the cervical spine, hypertension, hormonal or metabolic disorders) [11]. Hence, many authors are inclined to the view that, in adult patients, anatomical anomalies can only be diagnosed when other factors impair the vascularity of the central nervous system. A possible example of this involves reports that hypoplasia of the vertebral artery is more common in menopausal women, who often suffer from symptoms of vertebrobasilar insufficiency $[7,8]$.

Our previous studies [12] concerning the analysis of the frequency and types of anatomical anomalies of the cranial arteries (i.e. vertebral and carotid arteries) in patients with dizziness and impaired hearing showed that the most common anatomical anomaly of the cranial arteries was hypoplasia of the right vertebral artery, occurring in $58.7 \%$ of cases, of which $51.7 \%$ were women and $6.9 \%$ men; hypoplasia of the left vertebral artery, occurring in $24.7 \%$, of which $13.8 \%$ were women and $10.3 \%$ men; hypoplasia of the right internal carotid artery (in $3.4 \%$ of women) and of the left internal carotid artery (6.8\% of cases, $3.4 \%$ in women and $3.4 \%$ in men); and hypoplasia of the right common carotid artery (3.4\% of men); and critical stenosis of the left subclavian artery with subclavian steal syndrome was observed in $3.4 \%$ of women. Although the most common symptom occurring in these patients was tinnitus, the most common cause found in patients admitted to the clinic for diagnosis was dizziness, possibly because the patients found it more worrying.

With anatomical anomalies it is difficult to make any suggestions as to the nature of abnormalities without carrying out imaging tests. Diagnosis of anatomical abnormalities in the cranial arteries generally begins with vascular ultrasound. Blood flow disorders observed during the ultrasound should be further verified by contrast CTA or MRA to evaluate the morphology of the artery [2]. The diagnosis of vertigo, however, does not always involve contrast CTA of the cranial arteries. In our study, the ultrasound of the vertebrobasilar system showed no abnormalities in blood flow velocity, with a vascular anomaly only being suggested by pathological blood flow velocity found by ultrasound after applying the neck torsion test [5].
Normally, the unpaired basilar artery is formed by both vertebral arteries merging on the clivus of the occipital bone. In turn, the labyrinthine artery is a paired, thin vessel originating from the middle section of the basilar artery or from the anterior inferior cerebellar artery, which runs laterally along the atrio-cochlear nerve and enters the internal auditory canal to vascularize inner ear structures. The anterior inferior cerebellar artery is a paired vessel originating from the lower part of the basilar artery, finally merging with the posterior inferior cerebellar artery.

In the presented case, the basilar artery was an extension of the right vertebral artery, and the left atrophic vertebral artery extended into the posterior inferior cerebellar artery, while the labyrinthine artery originated bilaterally from the basilar artery.

The described vascular anomaly, along with osteochondrosis of the C4/C5 cervical spine and hyperlipidemia present in the patient resulted in mixed-type vertigo with decreased excitability of the labyrinth on the affected (anomalous) side due to insufficient blood supply to the inner ear and lack of vascular compensation of the vertebral artery on the other side.

Treatment of diagnosed anatomical anomalies in adults is usually conservative and depends on coexisting disorders. Surgical treatment for disorders of blood supply to the central nervous system caused by anomalous cranial vessels includes implantation of stents, arterial anastomosis, and vascular bypass [13].

In this case, conservative treatment and motor rehabilitation resulted in a very good outcome for the patient.

\section{Conclusions}

1. In this case of vascular anomaly, the basilar artery was an extension of the right vertebral artery, and the left atrophic vertebral artery extended into the posterior inferior cerebellar artery.

2. The vascular anomaly, osteochondrosis of the C4/C5 cervical spine, and hyperlipidemia resulted in mixed-type vertigo with decreased excitability of the labyrinth on the affected (anomalous) side due to insufficient blood supply to the inner ear and lack of vascular compensation.

3. The diagnosed anatomical anomaly of the vertebrobasilar system was not an indication for surgical intervention; therefore, conservative treatment was implemented.

\section{References}

1. Acar M, Degirmenci B, Yucel A, Albayrak R, Haktanir A. An evaluation of internal carotid artery and cerebral blood flow volume using color duplex sonography in patients with vertebral artery hypoplasia. Eur J Radiol, 2005; 53: 450-3.

2. Drobisz A T, Herfurt W. The vertebrobasilar syndrome and other pathologies of vertebral arteries by Doppler ultrasound. Udar Mózgu, 2001; 3(1): 35-41.
3. Olszewski J, Majak J, Pietkiewicz P, Łuszcz C, Repetowski M. The association between positional veretebral and basilar artery flow lesion and prevalence of vertigo in patients with cervical spondylosis. Otolaryngol Head Neck Surg, 2006; 134: 680-4.

4. Satomura S. Study of the flow patterns in the peripheral arteries by ultrasonic. J Acoust Soc Japan, 1995; 15: 151-8. 
5. Olszewski J, Zalewski P, Machała Z, Gaszyński W. The use of the neck torsion test in Doppler monitoring of the blood flow velocity in the vertebral arteries and the basilar artery in the brain of patients with cervical spine degeneration. Otolaryng Pol, 1994; 68(6): 549-55.

6. Poona M, Singla R K, Sharma T. Incidence of anomalous origins of vertebral artery: anatomical study and clinical significance. J Clin Diag Res, 2010; (4): 2626-31.

7. Mysior M, Majos A, Grzelak P, Szubert W, Stachowiak S, Stefańczyk L. Hypoplasia of the vertebral artery and symptoms of vertebrobasilar insufficiency in menopause. Przegląd Menopauzalny, 2007; 5: 298-302.

8. Paksoy Y, Vatansev H, Seker M, Ustun ME, Buyukmumcu M, Akpinar Z. Congenital morphological abnormalities of the distal vertebral arteries (CMADVA) and their relationship with vertigo and dizziness. Med Sci Monit, 2004; 10(7): 316-23.
9. Soustiel JF, Shik V, Shreiber R, Tavor Y, Goldsher D. Basilar vasospasm diagnosis: investigation of a modified "Lindegaard Index" based on imaging studies and blood velocity measurements of the basilar artery. Stroke, 2002; 33(1): 72-7.

10. Strupp M, Planck JH, Arbusow V, Steiger J, Bruckmann H, Brandt T. Rotational vertebral artery occlusion syndrome with vertigo due to "labyrinthine excitation". Neurology, 2000; 28(6): 1376-9.

11. Nissen RI, Harvey SA. Cerebrovascular Disease. In: Neurootology, ed. Jackler RD, Brackmann DE. Mosby, St Louis, 1994.

12. Miłoński J, Kuśmierczyk K, Mielczarek M, Niewiadomski P, Olszewski J. Anatomical anomalies of cranial arteries in patients with vertigo and hearing disorders. Otolaryng Pol, 2013; 67(20): 77-81.

13. Hopkins LN, Martin NA, Hadley MN, Spetzler RF, Budny J, Carter LP. Vertebrobasilar insufficiency. Part 2. Microsurgical treatment of intracranial vertebrobasilar disease. J Neurosurg, 1987; 66(5): 662-74. 
